Research.

\title{
Effect of capital structure and financial performance upon company value of automotive and components industrial subsectors which are registered in BEI
}

\author{
Syarief Gerald Prasetya ${ }^{1^{\star}}$, Raisa Nazila ${ }^{2}$ \\ $1^{1^{*}}$ Department of Accounting, Economic College of Binaniaga, Bogor, Indonesia \\ ${ }^{2}$ Department of Management, Economic College of Binaniaga, Bogor, Indonesia \\ er7et70@gmail.com (S. G. Prasetya), raisanazila@gmail.com (R. Nazila) \\ ${ }^{*}$ Corresponding author
}

Received: February 13, 2019; Accepted: April 28, 2019; Published: June 30, 2019.

To cite this article: Prasetya, Syarief Gerald, Raisa Nazila. (2019). Effect of capital structure and financial performance upon company value of automotive and components industrial subsectors which are registered in BEI. The Accounting Journal of BINANIAGA. 4 (1): 37-48. doi:

\begin{abstract}
Automotive industry is an industrial subsector that is attractive to be studied in a developing country and is one of the most important economic sectors in the world due to the revenue and strategic issue as it is not only providing a lot of benefits for national prestige, technology development, but also manpower employment. The purposes of this research are as the following: 1. To find out the effect of capital structure upon value of the company. 2. To find out the effect of financial performance upon value of the company. 3. To find out the effect of capital structure and financial performance upon value of the company. Population of this research is financial statement of manufacturing companies which is automotive and components industrial subsectors which are registered in the Indonesian Stocks Exchange (BEI) period 2009 - 2014. The samples are financial statement of the manufacturing companies registered in BEl. Data analysis instrument has applied multiple linear regression using SPSS software. Outcome of the research; 1. Capital structure variable partially has positively affected company value, therefore, in order to increase value of the company, variable of capital structure should have to be increased accordingly. 2. Financial performance variable partially has positively affected company value, therefore, in order to increase value of the company, variable of financial performance should have to be increased absolutely 3. Capital structure and financial performance variables simultaneously have positively affected company value. Independent variable which has mostly affected the company value is financial performance variable, it has been indicated by the value of $\beta$ Standardize Coefficience of 32.715
\end{abstract}

Keywords: Capital Structure, Financial Performance and Value of the company.

\section{Introduction}

\section{Background}

Automotive industry is an industrial sector which is very interesting to be studied in developing countries and it is one of the most important economic sectors in the world due to its revenue and strategic circumstance since it has provided a lot of benefits for the national prestige, technology development, and manpower employment as described below.

First, the development of automotive and its component industry will increase

Syarief Gerald Prasetya and Raisa Nazila. Effect of capital structure and financial performance upon company value of automotive and components industrial subsectors which are registered in $\mathrm{BEI}$ 
the national integrity and prestige. Capability of producing the component by local manpower is the symbol of independent economy (Wahyuni, 2010).

Second, automotive industry is directing the development of industrial subsectors to reach a high and modern technology of the industry (Wahyuni, 2010).

Third, automotive industrial subsectors are very large as they have been covering big industries, middle industries and small industries. The related industrial subsectors are producing iron, steel, non-ferros, plastic, rubber, glass, textile, machineries, suspension, fiber tissue industry, chemical, computer and telecommunication, electronics and other industrial components which is raw materials to manufacture automotive products. Nevertheless, these industries have employed a lot of manpower and required big capital (Wahyuni, 2010).

Getting along with a rapid development of automotive industrial technology at the moment, competitive automotive producers have to be able to design and to produce innovative goods that can meet market requirements. However, creating innovative new products will require big additional capital, but the company can get it from either internal current working capital from external parties which is the investors who are interested in investing their money.

Company capital structure is the combination of diversified shares (regular shares and preference shares) or mixed of all long-term financing (equities and liabilities) being utilized by the company, or in other words, capital structure is the key factors of developing company productivity and company performance (Kusumajaya, 2011).

Combination preference of capital structure is the most important thing in a company because it will influence cost of capital spending. Cost of capital is considered to which extent of return expected by the investors who invest their money. Finance managers should have to be fully aware of when and how much money will be required for capital budgeting and for maximizing capital structure (Sugiyono, 2009). When the company has a high value of the company but minimum cost of capital, it is indicated that the company has had optimal capital structure.

Referring to the theory of capital structure, if position of capital structure is higher than the target of optimal capital structure, every additional of liability required will decrease the company value. Defining the target of optimal capital structure is one of the management main responsibilities. And capital structure is the proportion of debt financing of the company which is leverage ratio. Therefore, liabilities are the resources of company capital structure. However, capital structure is the key factors to improve company productivity and performance. Nevertheless, theory of capital structure has described that financial policy of the company to define capital structure (mixed equities and liabilities) is increasing value of the company.

However, each company is required to maximize value of the company, because higher value of the company will make the investors interested in investing their money. Value of the company is one of important points being considered by investors, because, according to Saptadi (2007) shares price is the price determined by the interaction between selling and buying of the shares refers to background of the expected company revenue figuring out performance of the company which could influence the investor's perception.

Increasing of value of the company is affected by the system of company performance. And Value of the company is depending on the company financial statement itself. But. good company financial performance will be occured if good profitable relationship with other companies and consumers is good, otherwise they will go to other company. Nevertheless, if financial performance of the company is becoming worse, the consumers and investors are decreasing. Moreover, the decision of finance manager is directing the company to be either good or bad.

Syarief Gerald Prasetya and Raisa Nazila. Effect of capital structure and financial performance upon company value of automotive and components industrial subsectors which are registered in $\mathrm{BEI}$ 
This research is referred to the research of Yandi Arviansyah, 2013. But the difference between this research and the previous one is on the independent variables which is capital structure and financial performance.

Based on the background above, title of the research is as the following "Effect of Capital Structure and Financial Performance upon Company value of Automotive and Components Industrial Subsectors which are Registered in BEI"

\section{Research Design} following:

Referring to the background description above, research design is as the

a. To what extent is the effect of capital structure upon company value of automotive industries registered in BEl?

b. To what extent is the effect of financial performance upon company value of automotive industries registered in BEl?

c. To what extent is the effect of capital structure and financial performance upon company value of automotive industries registered in BEI?

\section{Purpose of the Research}

The purpose of this research is as follows:

a. To figure out the effect of capital structure upon company value.

b. To figure out the effect of financial performance upon company value.

c. To figure out the effect of capital structure and financial performace upon company value

\section{Library Review}

\section{Capital Structure}

Capital structure is a proportional description between capital investment coming from long-terms credits and assets of the company which is company's permanent financing method. Capital structure of a company is connected to the decision of investment project financing. And, bad decision of capital structure will produce high cost of capital and will reduce the revenue. However, effective decision of capital structure will reduce cost of capital and will get maximum revenue as well as company value improvement accordingly.

Optimal capital structure is capital structure maximizing a ratio between risk and return affecting shares price (Margaretha, 2011:112).

\section{Financial Performance}

Performance is a description about level of achievement of the program or policy reaching the target, objective, vision and mission that are described on strategic planning of an organization. And performance measurement is an evaluation of the achievement progress of the goals and targets defined before, including information about the efficiency of using all resources to produce goods and services, quality of goods and services, to define the output of activities compared to the result expected, and to use effective efforts achieving the goals (Mahsun, 2006).

Referring to Munawir (2008), performance measurement is data analysis and to control the company performing an improvement of the operational activities to become a competitive company. Inspite of that, measurement is the way how to exhibit company credibility to the investors or customers or society in general.

Syarief Gerald Prasetya and Raisa Nazila. Effect of capital structure and financial performance upon company value of automotive and components industrial subsectors which are registered in $B E I$ 


\section{Value of the Company}

An enterprise is an organization that is combining and organizing various resources to produce the goods and or services to be sold. Value of the company is not depending only on company capability to manage cash flow, but also on the operational characteristics as well as finance of the company that will be taken over.

For the companies which have not gone public yet, value of the company is depending on a certain amount of cost that prospect buyer would like to spend if the related company is sold. However, for the companies which have gone public, value of the company is indicated on its shares price in the Stocks Market. (Husnan, 2006).

Referring to Mahendra (2011) value of the company is very important due to high value of the company will increase the shareholders welfare. The higher the shares price is, the higher the company value will be. Meanwhile, high value of the company is the expectation of the owner, because it is indicating welfare of shareholders. Welfare of shareholders and company have been presented by market price of its shares indicating the decision making of financing and assets management.

\section{Research Design}

Based on the library review above, it has explained that $X_{1}$ is variable of Capital Structure, $X_{2}$ is variable of Financial Performance and $Y$ is variable of Company value, however, the three variables could be interconnected.

The following figure is the research design:

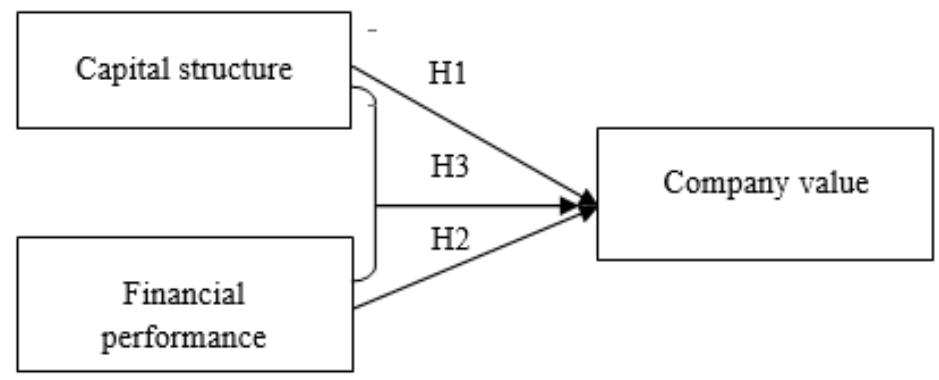

Figure 1

Research Design

\section{Hypotheses of the Research}

Based on the theory and research design above, hypotheses of the research are as the following:

$\mathrm{H} 1$ : There is the effect of capital structure upon company value of automotive and component industry.

H2: There is the effect of financial performance upon company value of automotive and component industry.

H3 : There is the effect of capital structure and financial performance upon company value of automotive and component industry.

\section{Research Methodology}

\section{Research Methodology}

This research has applied quantitative description which is the research figuring out value of independent variables, either one independent variable or more

Syarief Gerald Prasetya and Raisa Nazila. Effect of capital structure and financial performance upon company value of automotive and components industrial subsectors 
than one without comparing or connecting with other variable to get the data in numbers or qualitative data changed into the numbers. This research has been performed based on the financial statement of automotive and components indusrial subsectors for the period of 2009-2014 and which are registered in the Indonesia Stocks Exchange (BEI).

\section{Population and Samples}

Population of this research is financial statement of automotive and component subsectors of manufacturing companies registered in Indonesian Stocks Exchange period 2009 to 2014. Therefore, sampling coming from financial statement of manufacturing companies registered in $\mathrm{BEI}$ is expected could detect value of the company.

\section{Method of Data Sampling}

Data of the research are coming from the Indonesian Capital Market Directory (ICMD) period 2009-2014, Centers of Capital Market References (PRPM) at Indonesian Stocks Exchange, and from journals, textbooks and internet.

Data sampling of this research are theories coming from the library which is literatures and scientific journals as supporting materials for this research.

\section{Research Variable and Measurement}

a. Independent Variable (X)

1) Capital Structure

In this research, one of independent variable is capital structure. Referring to Riyanto (2008) capital structure is a balance and comparison between long-term liabilities and assets of the company. Long-term liabilities is a kind of long-term financing which is terms of payment more than one year.

Capital structure is measured by Debt to Equity Ratio (DER) by dividing total of long-term liabilities with total equity. The bigger the DER is, the bigger the debt of capital will be in order to obtain the revenue of company.

Debt to Equity Ratio $=\frac{\text { Total Debt }}{\text { Total Equity }}$

2) Financial Performance

Financial performance according to Rudianto (2013:189) is the outcome or achievement reached by the management running its function to manage assets of the company effectively in a certain period. Measuring financial performance can use the following equation:

Return on Assets $=$ Balance of the Revenue $\times 100 \%$

$$
\text { Total Assets }
$$

b. Dependent Variable $(Y)$ is company value.

Referring to Husnan (2013), value of the company is value of the market shares defined by market agents at a certain time. Value of the company is measured by Price Book Value (PBV) equation as follows:

Price Book Value $=\underline{\text { Price of the share }}$

$$
\text { Book value }
$$

Syarief Gerald Prasetya and Raisa Nazila. Effect of capital structure and financial performance upon company value of automotive and components industrial subsectors which are registered in $B E I$ 


\section{Method of Data Analysis}
a. Normality Test
b. Heteroscedasticity Test
c. Autocorrelation Test
d. Multiple Regression Model Test
e. Hypotheses Test
f. Adjusted R Square Test
g. T test
h. F test

\section{Analysis, Result and Discussion}

\section{Hypotheses Test}

a. Partial Test (T test)

Statistically $t$ test is applied to figure out whether or not each independent variable has affected dependent variable tested at sig. value of 0.05 . Outcome of test is indicated on table 1 below.

Table 1

Outcome of T test

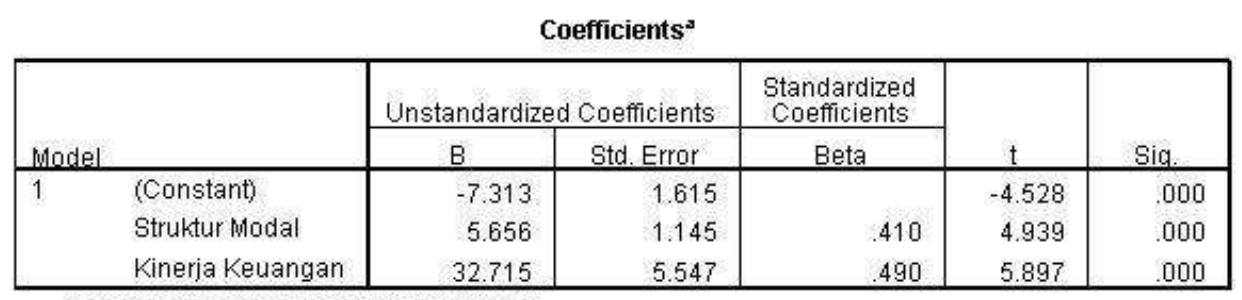

a. Dependent Variable: Nilai Perusahaan

Table 1 above has indicated the outcome of statistic $t$ test between independent variables and dependent variable. Variable of capital structure has indicated tcount value of 4.939 with sig.value of 0.000 . Since sig.value is less than 0.05 , it has explained that $\mathrm{Ho}$ is rejected and $\mathrm{Hi}$ is accepted, it means that variable capital structure has positively affected value of the company. Variable financial performance indicating tcount value of 5.897 with sig.value of 0.000 . Since sig.value is less than 0.05 explaining that $\mathrm{Ho}$ is rejected but $\mathrm{Hi}$ is accepted, nevertheless, variable financial performance has positively affected value of the company.

Based on the outcome of partial regression test on the table above, it is indicating that variable capital structure and variable financial performance partially have positively and significantly affected value of the company of Automative and Component industrial subsectors registered in BEI.

b. F test

$F$ test is applied to test whether regression model produced is significant or not. $F$ test can be applied by comparing $F_{\text {count }}$ with $F_{\text {table, if }} F_{\text {count }}>F_{\text {table, }}$ Ho is rejected but $\mathrm{Hi}$ is accepted, therefore this model is significant due to value of sig. columm (\%) is $<\alpha$. But on the contrary, if $F_{\text {count }}<F_{\text {table, }}$ this model is not significant due to the value of sig.column (\%) is $>\alpha$.

Outcome of $\mathrm{F}_{\text {test }}$ is indicated on the table 2 below:

Syarief Gerald Prasetya and Raisa Nazila. Effect of capital structure and financial performance upon company value of automotive and components industrial subsectors 
Table 2

Outcome of $\mathrm{F}$ test

\begin{tabular}{|c|c|c|c|c|c|c|}
\hline \multicolumn{7}{|c|}{ ANOVA $^{a}$} \\
\hline \multicolumn{2}{|l|}{ Model } & $\begin{array}{l}\text { Sum of } \\
\text { Squares }\end{array}$ & df & Mean Square & $\mathrm{F}$ & Sig. \\
\hline \multirow[t]{3}{*}{1} & Regression & 2102,651 & 2 & 1051,325 & 43,183 &, $000^{b}$ \\
\hline & Residual & 1825,944 & 75 & 24,346 & & \\
\hline & Total & 3928,595 & 77 & & & \\
\hline \multicolumn{7}{|c|}{ a. Dependent Variable: Nilai Perusahaan } \\
\hline \multicolumn{7}{|c|}{ b. Predictors: (Constant), Kinerja Keuangan, Struktur Modal } \\
\hline
\end{tabular}

Table 1 above has indicated that $F_{\text {count }}$ value is 43.183 with sig.value of 0.000 . Since sig.value is less than $0.05, \mathrm{Ho}$ is rejected but $\mathrm{Hi}$ is accepted or the model is significant.

So that, based on the outcome of $\mathrm{F}_{\text {test, }}$ it is concluded that variable capital structure and financial performance simultaneously has affected value of the company variable.

\section{Determinate Coefficient}

$R$ square value $\left(R^{2}\right)$ or determinate coefficient value is applied to measure to what extent the model can describe varied dependent variable. Small $R^{2}$ value is indicating that independent variables have had limited ability describing dependent variable. If the value is close to one, it explains that independent variables have provided almost all information required to predict varied dependent variable.

Table 3

Outcome of Determinate Coefficient Test

Model Summary ${ }^{b}$

\begin{tabular}{|l|l|r|r|r|}
\hline $\begin{array}{l}\text { Mode } \\
1\end{array}$ & $\mathrm{R}$ & $\mathrm{R}$ Square & $\begin{array}{c}\text { Adjusted } \mathrm{R} \\
\text { Square }\end{array}$ & $\begin{array}{c}\text { Std. Error of } \\
\text { the Estimate }\end{array}$ \\
\hline 1 & $.732^{2}$ & .535 & .523 & 4.93416 \\
\hline
\end{tabular}

a. Predictors: (Constant), Kinerja Keuangan, Struktur Modal

b. Dependent Variable: Nilai Perusahaan

Outcome of determinate coefficient test on table 8 above has indicated the value of $R^{2}$ of 0.523 explaining that dependent variable is able to be described by independent variables of $52.3 \%$, in other words, $52.3 \%$ of company value can be described by variable of capital structure and variable of financial performance, but the remaining of $47.7 \%$ is described by other factors which are not include in this research. Nevertheless, the other factors are the finance decision, dividend policy, investment decision and Corporate Social Responsibiliy.

\section{Multiple Linear Regression Analysis}

However, multiple linear regression output is the effect of capital structure and financial performance upon company value oft Automotive \& Component subsector industries registered in $\mathrm{BEI}$ as the following:

Syarief Gerald Prasetya and Raisa Nazila. Effect of capital structure and financial performance upon company value of automotive and components industrial subsectors which are registered in $\mathrm{BEI}$ 
Table 4

Outcome of Regression Analysis

\begin{tabular}{|c|c|c|c|c|c|c|}
\hline \multicolumn{7}{|c|}{ Coefficients $^{3}$} \\
\hline \multirow[b]{2}{*}{ Model } & & \multicolumn{2}{|c|}{ Unstandardized Coefficients } & \multirow{2}{*}{$\begin{array}{c}\begin{array}{c}\text { Standardized } \\
\text { Coefficients }\end{array} \\
\text { Beta }\end{array}$} & \multirow[b]{2}{*}{$t$} & \multirow[b]{2}{*}{ Sig. } \\
\hline & & $\mathrm{B}$ & Std. Error & & & \\
\hline \multirow[t]{3}{*}{1} & (Constant) & -7.313 & 1.615 & & -4.528 & .000 \\
\hline & Struktur Modal & 5.656 & 1.145 & .410 & 4.939 & .000 \\
\hline & Kinerja Keuangan & 32.715 & 5.547 & 490 & 5.897 & .000 \\
\hline
\end{tabular}

a. Dependent Variable: Nilai Perusahaan

The table 4 above is a regression equation figuring out the effect of capital structure and financial performance upon value of the company as follows:

$$
Y=-7,313+5,656 X_{1}+32,715 X_{2}
$$
follows:

Coefficients of multiple linear regression equation above can be described as

a. Figures of regression coefficient have indicated correlation of independent variables (capital structure, financial performance) with dependent variable (value of the company) of Automotive and Component industrial subsectors registered in $\mathrm{BEI}$. The more the increasing of independent variables (capital structure and financial performance) is happened, the more the increasing of dependent variable value (value of the company) will be at Automotive \& Components industrial subsectors registered in BEI.

b. Constant value on regression equation is -7.313 indicating that if other independent variables value is nul (zero), company value variable will be -7.313 It has explained that if capital structure variable and financial performance variable are within 0 position or constant, value of the company variable will be 7.313.

c. Regression coefficient of company structure variable (X1) of 5.656 indicating that if capital structure variable increases one point, company value variable will increase 5.656 unit when other variables are constant.

d. Regression coefficient of financial performance variable (X2) of 32.715 indicating that if financial performance variable is increased one point, company value variable will increase 32.715 unit when other variables are constant

e. The most dominant independent variable is financial performance variable refers to Standardized Coefficient value of $\beta$ is 32.715 , but $\beta$ capital structure is only 5.656 .

\section{Discussion}

Outcome of multiple regression test of each variable either capital structure or financial performance has affected significantly company value. This outcome is in accordance with previous research describing that capital structure and financial performance have affected significantly company value.

\section{a. The Effect of Capital Structure upon Company Value.}

Capital structure has affected positively and significantly value of the company. It is in accordance with the research done by Yandri Arviansyah (2013) describing that capital structure has affected positively value of the company

Result of this research is supported by findings done by Dewa Kadek Oka Kusumajaya (2011), defining that capital structure has affected positively and significantly company value.

Result of this research has indicated that capital structure has affected

Syarief Gerald Prasetya and Raisa Nazila. Effect of capital structure and financial performance upon company value of automotive and components industrial subsectors 
positively and significantly company value refers to regression coefficient of capital structure of 5.656 and signifant value of 0.000 which is explaining that each increasing of company capital structure of 1 unit will influence the increasing company value of 5.656 units.

\section{b. The Effect of Company Financial Performance upon Company Value}

Financial performance of the company has affected positively and significantly company value, this outcome is in line with the research of Anindyati Sarwindah Utami (2011) describing that financial performance has affected positively the company value.

This research has been supported by the research done by Yandri Arviansyah (2013) describing that company financial performance has had positive effect upon value of the company. Outcome of the research has obtained regression coefficient of financial performance of 32.715 and sig.value of 0.000 indicating that each increasing of company financial performance of I unit will affect the increasing value of the company of 32.715 units.

c. The Effect of Capital Structure and Financial Performance simultaneously upon the Company Value.

Result of hypotheses test has indicated that capital structure and financial performance have affected simultaneously and significantly the company value. This result is supported by the research done by Yandri Arviansyah (2013) defining that capital structure variable and company financial performance variable have positively affected company value.

And referring to the research of Anindyati Sarwindah Utami (2011) describing that capital structure and financial performance simultaneously have affected company value.

Outcome of the research has obtained the regression equation as follows $Y=-7,313+5,656 X_{1}+32,715 X_{2}$. Constant value of regression eequation of -7.313 indicating that if other independent variables are nul/zero, company value variable will decrease 7.313. Regression coefficient of capital structure variable (X1) of 5.656 indicating that if capital structure variable is increased one unit, compay value variable will increase 5.656 units accordingly, but other variables are constant. Regression coefficient of financial performance variable (X2) of 32.715 indicating that if financial performance is increased one unit, company value variable will increase 32.715 units when other variables are constant. The most dominant independent variable is financial performance variable refers to Standardized Coefficient value which is $\beta$ of 32.715 , however $\beta$ capital structure of 5.656 .

\section{Conclusion and Suggestions}

\section{Conclusion}

This research aims to figure out the effect of capital structure and financial performance upon the company value of Automotive and Component industrial subsectors registered in BEI period 2009-2014.

Based on the data collected and test being done upon 13 companies as the samples using multiple regression model, the conclusion are as follows:

a. Capital structure variable partially has affected positively the company value, therefore, in order to increase value of the company, the related companies should have improved variable of capital structure.

b. Financial performance variable partially has affected positively the company

Syarief Gerald Prasetya and Raisa Nazila. Effect of capital structure and financial performance upon company value of automotive and components industrial subsectors which are registered in $B E I$ 
value, therefore, in order to increase value of the company, the related companies should have improved variable of financial performance.

c. Capital structure variable and financial performance variable simultaneously have affected positively the company value. The most dominant independent variable affecting company value is financial performance variable, it is indicated by $\beta$ value of Standardize Coefficience of 32.715 .

\section{Suggestions}

Outcome of this research is expected providing the description of the effect of capital structure and financial performance upon value of the company. However, this research has still been having some limits. These kind of limits are expected providing a description and opportunity for next researchers who will do the research better. The following issue of limitation and suggestions which are to be considered by next researcher:

a. Sample of this research has only one index which is the index of automotive and components industrial subsectors, so that, it has not covered yet all the findings for all public enterprises. Therefore, next researchers are suggested to add and connect other index such as LQ45 in their research, so that, population that will be the samples of the research are not only index of automotive and component subsectors, but also other index to provide accurate detection of company value.

b. Model applied to detect company value in this research probably has not yet detected company value quite good since it has been a complicated model which could have made some mistakes on the data processing. Therefore, next researchers could apply other model which is more simple and more accurate.

c. This research has applied only two independent variables to evaluate some factors which can affect company value. Therefore, next researchers can add new variables and correlate them to find out other factors affecting value of the company.

d. This research has only applied one ratio analizing two independent variables to evaluate some factors which have affected company value. Therefore, next researchers can put additional ratio, so that the calculation will be more accurate.

\section{References}

Besley, S., Brigham, F.E. (2000). Essentials of Managerial Finance. Eleventh Edition. Florida: The Dryde $\mathrm{n}$ Press.

Brigham, F.E., Houston, J. (2010). Dasar-Dasar Manajemen Keuangan: Assetials of Financial Management. Jakarta: Salemba Empat.

Frank J.F. (1999). Manajemen Investasi, Edisi Indonesia. Jakarta: Salemba Empat.

Ghazali, I. (2012). Aplikasi Analisis Multivariate dengan Program IBM SPSS 19. Semarang: Badan Penerbit Universitas Diponegoro.

Harahap, S.S. (2008). Analisis Kritis Atas Laporan Keuangan. Jakarta: Raja Grafindo Persada.

Bourgeois, L.J., Kathleen, M. (1988). Eisenhardt. Management Science Journal. 34 (7).

Kasmir. (2009. Analisis Laporan Keuangan.Jakarta: PT. Raja Grafindo Persada.

Syarief Gerald Prasetya and Raisa Nazila. Effect of capital structure and financial performance upon company value of automotive and components industrial subsectors 
Keown, J., Arthur, J.D., Martin, J., William,P., David, F., Scott, J.R. (2011). Manajemen Keuangan, Edisi Kesepuluh. PT. Indeks.

Kusumajaya, D.K.O. (2011). Pengaruh Struktur Modal dan Pertumbuhan Perusahaan Terhadap Profitabilitas dan Nilai Perusahaan pada Perusahaan Manufaktur di Bursa Efek Indonesia. Tesis Universitas Udayana. Denpasar.

Lukman, S. (2009). Manajemen Keuangan Perusahaan: Konsep Aplikasi dalam Perencanaan, Pengawasan, dan Pengambilan Keputusan (Edisi Baru). Jakarta: PT. Raja Grafindo Persada.

Mahendra, A. (2011). Pengaruh Kinerja Keuangan terhadap Nilai Perusahaan (Kebijakan Deviden sebagai Variabel Moderating) pada Perusahaan Manufaktur di Bursa Efek Indonesia. Universitas Udayana. Tesis. Denpasar.

Margaretha, F. (2011). Manajemen Keuangan untuk Manajer Non Keuangan. Jakarta: Erlangga.

Martono., Harjito, A. (2005). Manajemen Keuangan. Yogyakarta: Ekonisia.

Moeljadi. (2006). Manajemen Keuangan Pendekatan Kuantitatif dan Kualitatif, Jilid 1. Malang: Bayumedia Publishing.

Nainggolan, P. (2004). Cara Mudah Memahami Akuntansi. Jakarta: PPM. 2004

Sangadji, E., Sopiah. (2010). Metodologi Penelitian Pendekatan Praktis dalam Penelitian. Yogyakarta: Andi. 
The Accounting Journal of BINANIAGA Vol. 04, No. 01, June 2019

p-ISSN: $2527-4309$, e-ISSN: $2580-1481$

$5^{\text {th }}$ Accreditation Rating: January 14, 2019 - January 13, 2024

This page intentionally be emptied.

Syarief Gerald Prasetya and Raisa Nazila. Effect of capital structure and financial performance upon company value of automotive and components industrial subsectors which are registered in $B E I$ 